\title{
POVEZANOST STRUKTURE OČEKIVANJA ISHODA TRETMANA I KLINIČKE SLIKE KOD PSIHIJATRIJSKIH PACIJENATA ${ }^{1}$
}

\author{
Dragana Brdarić i Vesna Gavrilov- Jerković², \\ Odsek za psihologiju, Filozofski fakultet, Novi Sad
}

U ovom radu autori su se zainteresovali da istraže prirodu očekivanja koja razvijaju psihijatrijski pacijenti u odnosu na ishod tretmana, kao i povezanost tih očekivanja sa vrstom i izraženošću problema zbog kojeg se trenutno nalaze na psihijatrijskom tretmanu.

Ispitivano je četiri vrste očekivanja koja se odnose na ishod tretmana: specifični lokus kontrole, specifična i generalna self-efikasnost i percepcija kontrole. Od kliničkih varijabli korišćene su dijagnoze poremećaja kao i indeks uznemirenosti (Globalni indeks ozbiljnosti stanja). Istraživanje je sprovedeno na 129 ispitanika koji su u vreme ispitivanja bili uključeni u tretman na psihijatrijskim ustanovama u Vojvodini.

Klaster analizom je ustanovljeno postojanje šest interpretabilnih grupa ispitanika u odnosu na profile očekivanja ishoda tretmana: obeshrabreni internalisti, umerenjaci, samouvereni internalisti, bespomoćni eksternalisti, samouvereni eksternalisti i situacioni optimisti.

Dalje analize su pokazale da među dobijenim klasterima postoje statistički značajne razlike u pogledu nivoa indeksa uznemirenosti i pripadnosti pojedinoj dijagnostičkoj kategoriji. Rezultati govore u prilog teorijskim prepostavkama da su visoka očekivanja kontrole i efikasnosti povezana sa boljim stanjem ispitanika, ali i da postoji složen odnos među pojedinačnim merama očekivanjima ishoda tretmana. Kao najbolji prediktor se pokazala percepcija kontrole. Uticaj specifičnog lokusa kontrole je, i pored značajne korelacije sa stanjem pacijenta gde promena ka unutrašnjem lokusu prati bolje stanje ispitanika, ipak nejasan, nedosledan i zavistan od ostalih očekivanja ishoda tretmana.

Ključne reči: očekivanje, lokus kontrole, self-efikasnost, perecepcija kontrole, klinička populacija

\footnotetext{
${ }^{1}$ Rad u okviru projekta „Psihološke karakteristike društva u tranziciji“ koji finansira Ministarstvo nauke i zaštite životne sredine RS

${ }^{2}$ E-mail: jerkovso@eunet.yu
} 


\section{Uvod}

Svaki čovek koji se nađe pred novom situacijom, naročito ukoliko je ona nepovoljna ili neočekivana, pokušava da je sebi razjasni. U okvirima zapadne civilizacije, jedan od važnih zadataka u razumevanju određenog događaja je utvrđivanje šta je dovelo do njega, tj. pronalaženje odgovora na pitanje zašto. Uzroke pojavama ljudi traže u svojim karakteristikama ili spoljašnjim faktorima. Zatim procenjuju da li nad događajima poseduju kontrolu ili su oni nekontrolabilne prirode, kao i da li imaju potrebne sposobnosti da njima ovladaju.. Često pri tome ne raspolažu svim relevantnim informacijama, ili podležu raznim „iskrivljenjima” stvarnosti. Iz ovoga proizilazi da zaključci o nastanku i prirodi pojedinog događaja nisu uvek realni i tačni. Međutim, bez obzira na njihovu tačnost, psihologe je zanimalo da li ovi zaključci, u kojoj meri i na koji način utiču na to kako će osoba gledati na sebe i kakve će ishode sličnih događaja u budućnosti očekivati.

Odgovore na ova pitanja tražile su mnoge psihološke teorije. Jedan od prilaza ponudile su nam rane teorije motivacije kao što su Frojdova, Lorencova i Halova, (Freud, Lorenz, Hull, po Weiner-u, 1992). Sredinom prošlog veka, one su zamenjene shvatanjima o učešću viših kognitivnih funkcija u procesu donošenja odluka i reagovanja. Golmanova istraživanja su prva u nizu koja potkrepljuju takvo gledište (Golman, 1932, po Weiner, 1992). Istraživanja latentnog učenja su ukazivala na uticaj privlačnosti cilja na akciju, kao i na uticaj očekivanja da će određena akcija biti praćena odgovarajućim odgovorom. Tako su u žižu interesovanja motivacionih teorija dospela i očekivanja. U daljem tekstu ćemo se više pozabaviti teorijskim razmatranjima očekivanjima, i to lokusom kontrole, self-efikasnošću i percepcijom kontrole.

\section{Lokus kontrole}

Roter je lokus kontrole definisao kao ljudsko očekivanje da će unutrašnji, odnosno spoljašnji faktori uticati na ishode događaja. Roterova teorija predviđa, a brojna istraživanja ukazuju da je adaptivnije verovanje u uticaj unutrašnjih faktora na ishode događaja (Rotter, 1954; Forsterling, 1988). Osobe koje procenjuju da su zaslugom sopstvenih osobina došle do željenog cilja zauzimaju aktivniji stav u sličnim budućim situacijama, motivisanije su da se zalažu u prevladavanju eventualnih prepreka i zadovoljnije su sobom. One koje, suprotno, procenjuju da su do rezultata došle igrom slučaja, ili pak da su za to zaslužni drugi, razvijaju pasivniji stav, manje su motivisane da se u narednim situacijama trude i sl. (Beitel, Ferrer \& Cecero, 2004). Međutim, ukoliko je u 
pitanju procena negativnog ishoda, izgleda da može biti manje adaptivno zauzeti unutrašnji lokus kontrole nego spoljašnji. Stav da je neuspeh rezultat unutrašnjih karakteristika može da pasivizira i obeshrabri osobu u daljim zalaganjima, kao i da negativno utiče na procenu sopstvene efikasnosti i osećaja kontrole. Suprotno, posedovanje spoljašnjeg lokusa pri eventualnom neuspehu može pozitivno da utiče na motivaciju i sliku o sebi. (Abramson et al, 1978).

Furnhem i Stil su kritikovali originalnu Roterovu skalu generalnog lokusa kontrole zbog slabe prediktivnosti. Po njihovom mišljenju, opravdana je česta pojava da autori istraživanja konstruišu nove, za određenu sferu specifične mere lokusa kontrole. Jedna od njih je MHLC skala Voltsona i saradnika. (Furnham, Steele 1993)

Podaci o ovom konstruktu su relativno oskudni kada je u pitanju klinička populacija. Dalja istraživanja bi mogla da daju odgovor na pretpostavke o terapijskim implikacijama orijentacije lokusa kontrole, među kojima je i pretpostavka da bi, usmeravanjem lokusa kontrole u željenom pravcu, uticali pozitivno na self-koncept i motivaciju klijenata za terapijski rad. (Nir \& Neumann, 1995; Jerković i Gavrilov-Jerković, 1997; Jerković, 2003).

\section{Self-efikasnost}

Procena ljudi da će posedovati odgovarajuće veštine u izlaženju na kraj sa određenom situacijom, pokazano je u brojnim istraživanjima, utiče pozitivno na stvarno ponašanje i uspeh. (Bandura, 1982) S obzirom da je u terapiji jedan od važnih ciljeva promena ponašanja u određenom pravcu, procena self-efikasnosti može da posluži kao koristan prediktor promene i smernica pri odabiru odgovarajućih terapijskih intervencija (Gavrilov-Jerković, 2007). Originalan Bandurin koncept self-efikasnosti odnosi se na specifičnu, za situaciju vezanu procenu sopstvene efikasnosti (Bandura,1977, po Brewin, 1984). Među brojnim istraživanjima ovog koncepta nalaze se i ona koja su se bavila tretmanom fobičnog ponašanja i poremećaja zavisnosti. Ona daju rezultate o značajnoj povezanosti između visoke self-efikasnosti i napretka ka željenom ponašanju (Brewin, 1988). Ovakvi nalazi podstiču na dalje istraživanje ovog koncepta u kliničkoj populaciji. Međutim, istraživanja takođe ukazuju na to da, što je simptomatologija bogatija, to je veza između mere specifične self-efikasnosti i ponašanja nejasnija. (Suynder i Forsyth, 1990) U tu svrhu se predlaže upotreba mere generalne self-efikasnosti koja pokriva širi opseg situacija. (Schwarzer, Jerusalem 2002) 


\section{Percepcija kontrole}

Percepcija kontrole predstavlja očekivanje osobe o tome da li će posedovati kontrolu nad situacijom. Među teoretičarima koji naglašavaju značaj percepcije kontrole na mentalno zdravlje individue je i Bandura, koji interpretirajući nalaze svojih istraživanja, govori o povezanosti simptoma anksioznosti sa percepcijom nedostatka kontrole nad stresnim i zahtevnim situacijama. (Bandura 1994) Ukoliko klijent procenjuje da je za uspeh u terapiji presudno lično zalaganje, to nam govori o njegovom unutrašnjem lokusu kontrole. Ako bismo se oslanjali samo na ovaj podatak, govori Bandurina socijalno-kognitivna teorija, mogli bismo doneti pogrešan zaključak da će se, imajući ovakav stav, osoba obavezno vredno zalagati i biti aktivna u terapiji. Naime, osoba može procenjivati da, iako zalaganje smatra važnim, ona lično nije sposobna ili nije u mogućnosti da se zalaže za taj cilj, da nema adekvatnu podršku okoline i sl. U tom slučaju će njeno zalaganje biti manje nego u slučaju da procenjuje da ima uticaja nad situacijom. Ovde je vidljivo da se Bandurin koncept percepcije kontrole približava konceptu self-efikasnosti. (Bandura, 1982)

Sa druge strane, neki od modela ukazuju na potrebu razlikovanja ova dva pojma. Takva je teorija planiranog ponašanja autora Icek Ajzena (Ajzen, 2002) koji pitanje kontrolabilnosti obrađuje preko pojma percepcije bihejvioralne kontrole. Po ovoj teoriji, ljudsko ponašanje zavisi od tri vrste verovanja. Prvu čini procena verovatnoće da će ponašanje dovesti do željenih posledica (behavioral beliefs). Druga su verovanja o očekivanjima drugih ljudi (normative beliefs). Treća vrsta verovanja se odnosi na faktore koji mogu olakšati ili omesti izvršavanje određenog ponašanja (control beliefs). Ova „verovanja o kontroli" su osnov opaženoj bihejvioralnoj kontroli. Njegova teorijska pretpostavka je da će visok nivo percepcije bihejvioralne kontrole jačati nameru osobe da izvrši određenu akciju, kao i da će pojačavati ulaganje truda i istrajnosti $\mathrm{u}$ akciji. U okviru teorije planiranog ponašanja, navode se dva pristupa merenju percipirane bihejvioralne kontrole. Autor (Ajzen, 2002) daje prednost takozvanom indirektnom pristupu merenja (merenje verovanja o kontroli) koji pruža uvid u kognitivne osnove percepcije kontrole. Ispitanicima bi najpre bilo dato da formiraju listu faktora za koje veruju da bi im mogli olakšati ili otežati izvršenje određene akcije. Zatim bi im se davao upitnik formiran, ili od faktora koji su sami naveli, ili od najčešće navođenih faktora. Ispitivanje ovih faktora uključuje procenu verovatnoće da će dati kontrolni faktor biti prisu$\tan$. Iz studija vršenih na ovaj način, uočeno je da ispitanici kao kontrolne faktore spontano navode kako unutrašnje (znanje, veštine, snaga volje i sl), tako i spoljašnje uzroke (težina zadatka, pomoć drugih, pristupačnost u vremenu ili novcu itd). 
Jedan od teorijskih okvira koji uključuje percepciju kontrole je i teorija akcije (Skinner i saradnici, 1988, po Musher-Eizenman, Nesselroade i Schmitz, 2002) koja objašnjava kako percepcija kontrole utiče na ishode određene situacije. Po ovim autorima, verovanja o kontroli utiču na ponašanje i emocionalno stanje, zatim to ponašanje i emocije vode do ishoda, te ishod ponovo utiče na verovanje. Kada je procena kontrole visoka, osoba je aktivna, a emocije su joj generalno pozitivne, što sve vodi pozitivnim ishodima i porastu percepcije kontrole. Ukoliko je, međutim procena kontrole niska, ona vodi pasivnosti, izbegavanju izazovnih zadataka i emocijama poput anksioznosti i straha.

Iz prikazanih teorijskih pristupa se vidi da ne postoji jedinstven stav o prirodi konstrukta percepcije kontrole. Ovu zbrku povećava i terminološka šarolikost koja se sreće u literaturi. Naime, u brojnim istraživanjima se, pod imenom „percepcija kontrole” nalaze konstrukti različite opštosti i značenja, kao i što se pojavljuje nekoliko naziva u objašnjavanju iste stvari (npr. perception of control, perceived control, perceived controlability...). Očigledno da je za sada teško dati univerzalno prihvaćenu definiciju percepcije kontrole jer operacionalizacija ovog pojma zavisi od usvojenog teorijskog modela.

\section{Očekivanje ishoda tretmana}

Iz prethodnih teorijskih opisa vidljivo je da je reč o bliskim, delimično ili potpuno preklapajućim konstruktima, o čijem međusobnom odnosu postoji veoma malo istraživanja, pogotovo onih koja uključuju kliničku populaciju. Iz tog razloga, zanimali smo se upravo za istraživanje međusobnog odnosa očekivanja u kliničkom kontekstu. Specifičan lokus kontrole, generalna i specifična self-efikasnost i percepcija kontrole su ispitivani kao očekivanja ishoda samog tretmana kod ispitanika, učesnika u psihijatrijskom lečenju.

Vođeni predlogom autora koji su napravili pregled skala za merenje lokusa kontrole (Furnham, Steele 1993), konstruisali smo instrument specifičnog lokusa kontrole koji se odnosi na neuspeh psihijatrijskog tretmana. Instrument je konstruisan sa namerom da meri specifičnu sklonosti pacijenta da eventualne nepovoljne ishode psihijatrijskog tretmana pripiše spoljašnjim ili unutrašnim faktorima.

Takođe, korišćene su skale specifične i generalne self-efikasnosti. Specifična self-efikasnost se odnosi na procenu sopstvene sposobnosti da se suoči sa situacijom psihijatrijskog tretmana, dok generalnom self-efikasnošću ispitanici izražavaju stepen uverenosti u sopstvene snage uopšteno gledano.

Dalje, od ispitanika je traženo da procene stepen sopstvene kontrole nad situ- 
acijom psihijatrijskog lečenja. Faktori koji su navođeni kao mogući uzroci neuspeha tretmana kod merenja specifičnog lokusa kontrole, ovde su ponovo činili ajteme, s tim što pitanje više nije bilo predviđanje uzroka neuspeha, već procena mere aktuelnog posedovanja kontrole nad opisanim faktorima.

Konačno, konsultujući literaturu, uvideli smo da povezanost ovih konstrukta sa različitim vrstama i težinom patologije nije dovoljno rasvetljena, a mogla bi ponuditi korisne informacije o eventualnoj potrebi prilagođavanja tretmana, tj. pružanja odgovarajućih intervencija. Stoga smo ispitivali i povezanost ovih mera očekivanja ishoda tretmana sa kliničkim karakteristikama uzorka. Od kliničkih varijabli koristili smo dijagnostičku kategoriju ispitanika i indeks uznemirenosti dobijen putem Derogatisove ček liste simptoma.

\section{Metod}

\section{Uzorak}

Uzorak je činilo 129 ispitanika koji su u vreme sprovođenja ispitivanja bili pacijenti u pet psihijatrijskih ustanova u Vojvodini (Novi Sad, Sombor, Subotica, Zrenjanin i Sremska Mitrovica). Starost ispitanika se kretala od 22 do 58 godina, a većinu su činile žene $(75,2 \%)$. Veći broj pacijenata iz uzorka je bio na hospitalnom ili poluhospitalnom tretmanu, njih 90, koji su ispitani tokom prve nedelje od prijema. Manji deo uzorka, koji je brojao 39 ispitanika, bio lečen ambulantno i ispitan je prilikom prvog javljanja psihologu. Ispitivanje su vršili psiholozi zaposleni u datim ustanovama davanjem instrumenata u okviru redovnog dijagnostičkog postupka. Polovina uzorka je učestvovala i u programima dnevnih bolnica. Ispitanici su bili pacijenti sa dijagnozama iz reda neurotskih poremećaja i poremećaja ličnosti. Raspored ispitanika po dijagnostičkim kategorijama je sledeći: anksiozno-depresivni $(\mathrm{N}=43)$, somatoformni $(\mathrm{N}$ $=25)$, depresivni $(\mathrm{N}=38)$, poremećaji ličnosti $(\mathrm{N}=14)$ i panični poremećaji $(\mathrm{N}=9)$.

\section{Instrumenti}

Skala specifičnog lokusa kontrole (ASOK-2001; Gavrilov-Jerković, 2003). Skala sadrži deset stavki koje se odnose na moguće razloge neuspeha psihijatrijskog tretmana. Pet stavki se odnosi na unutrašnje (lično angažovanje, upornost, promena navika...), a pet na spoljašnje (podrška okoline, sposobnost terapeuta, „viša sila”...) potencijalne uzroke neuspeha tretmana. Od ispitanika se traži 
da označi pet stavki koje smatra najznačajnijim uzrocima za datu hipotetičku situaciju. Proverom pouzdanosti instrumenta dobijen je Kronbahov alfa u visini od 0.78 .

Skala percepcije kontrole (PK; Gavrilov-Jerković, 2003). Od ispitanika se ovom skalom traži procena stepena kontrole nad faktorima relevantnim za (ne)uspeh psihijatrijskog tretmana. Preciznije, traže se odgovori na pitanje u kojoj meri aktuelno, dok se nalaze na psihijatrijskom tretmanu, procenjuju da poseduju kontrolu nad svakim faktorom nabrojanim u skali specifičnog lokusa kontrole (lično angažovanje, sopstvena upornost, podrška okoline...) Procena stepena posedovanja kontrole nad datim stavkama se izražava petostepenom skalom Likertovog tipa. Po ugledu na Ajzenov način merenja percepcije kontrole, (Ajzen, 2002) rezultati se boduju tako što se za ajteme koje je ispitanik na skali specifičnog lokusa kontrole obeležio kao najznačajnije, sabiraju bodovi. Analizom pouzdanosti Skale percepcije kontrole na našem uzorku je utvrđen koeficijent alfa u vrednosti od 0,795.

Skala generelne self-efikasnosti (SGSE; Scwarzer, Jerusalem, 2002). Skala sadrži 10 ajtema, a odgovori na skali predstavljaju stepen slaganja ispitanika sa datom tvrdnjom. Konačni skor se dobija zbrajanjem bodova sa pojedinačnih ajtema. Vrednosti interne pouzdanosti u brojnim studijama, kreću se od 0,75 do 0,92. (Scwarzer i Jerusalem, 1999). Takođe je analiza glavnih komponenata u kros-kulturalnim istraživanjima pokazala da je u pitanju jednodimenzionalni instrument (Scwarzer i Born, 1997, po Gavrilov-Jerković, V, 2003).

Skala specifične self-efikasnosti (SSSE; Gavrilov-Jerković, 2003). Konstruisana je po ugledu na prethodnu skalu generalne self-efikasnosti. Skala se odnosi na situaciju psihijatrijskog tretmana, $\mathrm{tj}$. ajtemima je iskazano poverenje u sopstvene sposobnosti koje doprinose pozitivnom razrešenju terapijske situacije. Sastoji se od devet stavki u kojima se ispitanici opredeljuju za jedan od pet stepena slaganja sa tvrdnjom. Pouzdanost izračunata metodom Cronbach alfe je 0,86 a Split-half metodom .85. Faktorska analiza instrument predstavlja kao jednodimenzionalni.

Ček lista simptoma 90-R (SCL-90-R; Derogatis i Savitz, 1999) predstavlja samoopisnu meru trenutnog simptomatološkog stanja pacijenta. Upitnik sadrži 90 stavki. Skala se skoruje preko petostepene Likertove skale. Za potrebe ovog istraživanja korišćen je samo jedan od tri indikatora uznemirenosti, a to je Globalni indeks ozbiljnosti stanja (Global Severity Index (GSI)). U raznim istraživanjima pouzdanost instrumenta merena koeficijentom alfa ima vrednost u rasponu od 0,77 do 0,90. (Olsen i saradnici, 2004, prema Amroš, J, 2006) 


\section{Rezultati}

Najpre smo uradili klaster analizu nad standardizovanim merama očekivanja $(A S=50, S D=10)$. Ovako dobijeni klasteri omogućili su nam uvid u strukturu odnosa među samim merama očekivanja i dalje njihovo poređenje sa kliničkim karakteristikama.

Na osnovu hijerarhijske analize, koristeći Euklidove distance, dobijen je rezultat koji sugeriše da je optimalno zadržati šest klastera. Zatim je izvršena nehijerarhijska analiza sa zadatih šest klastera. S obzirom na mali broj ispitanika koji je ušao u šesti klaster, pokušano je i

sa alternativnim metodama izračunavanja klastera, ali se nisu dobijale nikakve suštinske razlike, čak su i dobijana manje interpretabilna rešenja, tako da je zadržana varijanta koja je bila i statistički i logično opravdana, s tim da je potrebno sa oprezom interpretirati šesti klaster. Prosečne vrednosti dobijenih profila prikazane Grafikom br. 1, daju jasniju sliku o sličnostima i razlikama u okviru datih varijabli.

Grafikon 1. Prosečne vrednosti klastera

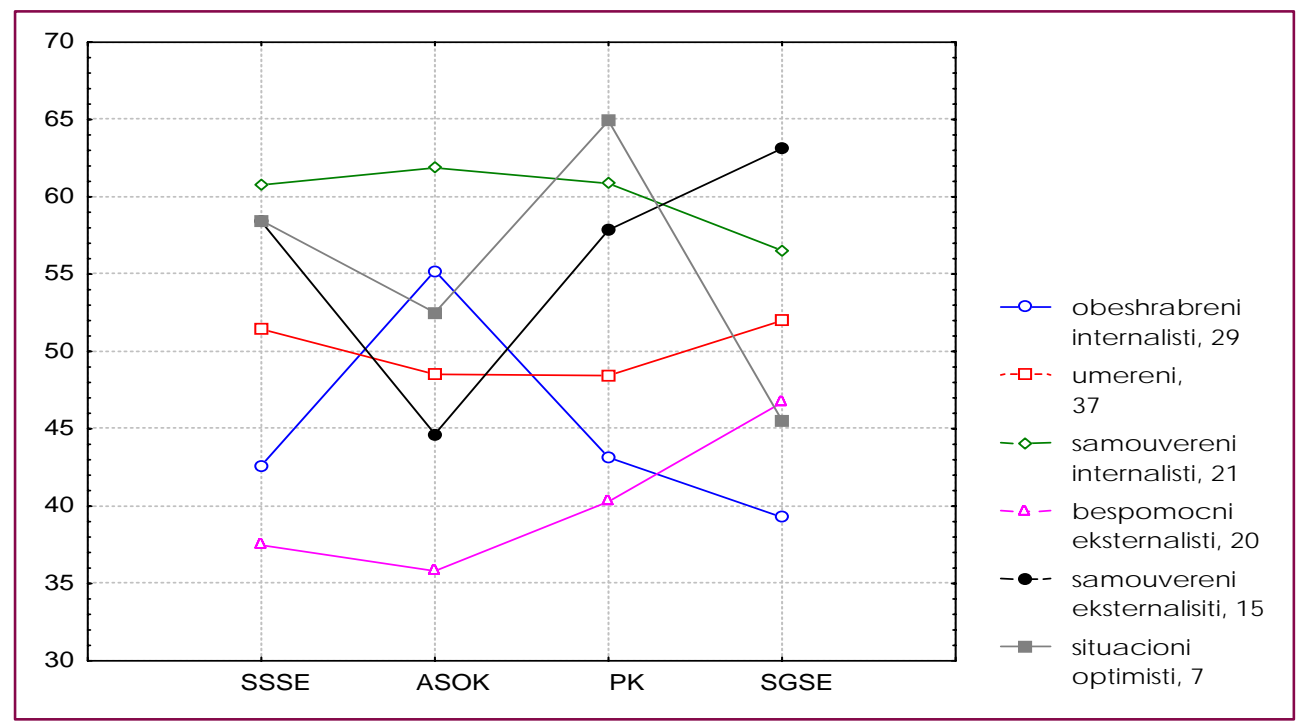

Prvi klaster, nazvan obeshrabreni internalisti, čine 29 ispitanika čije su prosečne vrednosti specifične i generalne self-efikasnosti, kao i percepcije kontrole, oko jednu standardnu devijaciju ispod proseka, dok je aritmetička sredina mere specifičnog lokusa kontrole za pola standardne devijacije od proseka, u smeru unutrašnjeg lokusa. 
Drugi klaster pod nazivom umereni formira 37 subjekata. Skorovi na merama očekivanja se nalaze na nivou proseka, $\mathrm{s}$ tim što se blago iznad proseka nalaze mere self-efikasnosti, a blago ispod proseka mere kontrole.

Treći klaster, samouvereni internalisti, sastoji se od 21 subjekta. Ovaj klaster karakteriše generalno najviše vrednosti na merama očekivanja ishoda tretmana. Mera koja najviše odstupa od proseka je mera specifičnog lokusa kontrole u smeru unutrašnjeg lokusa.

Četvrti klaster pod nazivom bespomoćni eksternalisti čini 20 ispitanika. Vrednost specifičnog lokusa kontrole se nalazi na udaljenosti od jedne i po standardne devijacije od proseka u smeru spoljašnjeg lokusa. Mera percepcije kontrole i specifične self-efikasnosti su oko jednu standarndnu devijaciju ispod proseka. Mera generalne self-efikasnosti se nalazi u blizini proseka.

Peti klaster imenovan kao samouvereni eksternalisti čini 15 ispitanika. Prosečne vrednosti specifične self-efikasnosti i percepcije kontrole nalaze se približno jednu devijaciju iznad proseka. Specifični lokus kontrole je blago usmeren ka spoljašnjem polu, dok je generalna self-efikanost na više od jedne standardne devijacije iznad proseka.

Šesti klaster, situacioni optimisti, sastoji se od 7 ispitanika. Procena kontrole je kod ovih ispitanika najviše izražena, kako u odnosu na druge mere očekivanja, tako i u odnosu na percepciju kontrole u ostalim grupama. Procena specifične self-efikasnosti je takođe visoko iznad proseka, dok je procena globalne self-efikasnosti blago ispodprosečna.

Nakon grupisanja ispitanika u klastere, vršena je procena statističke značajnosti razlika među grupama preko analize varijanse. Dobijena je statistički značajna razlika na nivou značajnosti od 0,001 . (Tabela 1 )

Tabela 1. Anova: testiranje značajnosti razlika između klastera

\begin{tabular}{lcc}
\hline St. slobode & $\mathrm{F}$ & $\mathrm{p}$ \\
\hline 5 & 5.85 & .00 \\
\hline
\end{tabular}

Shaeffe-ov post hoc test (Tabela 2) je pokazao značajne razlike između klastera bespomoćni eksternalisti (klaster br. 4), i klastera umereni, samouvereni internalisti i situacioni optimisti (klasteri 2, 3 i 6). 
Tabela 2. Post hoc testiranje statističke značajnosti razlika medu klasterima, Scheffe test

\begin{tabular}{|c|c|c|c|c|c|c|c|}
\hline & $\{1\}$ & \multicolumn{2}{|l|}{2} & $\{3\}$ & $\{4\}$ & $\{5\}$ & $\{6\}$ \\
\hline AS & 6.30 & \multicolumn{2}{|c|}{5.09} & 4.54 & 7.04 & 5.82 & 3.78 \\
\hline 1 & & & & & & & \\
\hline 2 & .29 & & & & & & \\
\hline 3 & .09 & .96 & & & & & \\
\hline 4 & .89 & .03 & .01 & & & & \\
\hline 5 & .99 & .92 & .60 & .65 & & & \\
\hline 6 & .11 & .76 & .98 & .02 & .40 & & \\
\hline
\end{tabular}

Potom je ispitivana veza između pripadnosti određenom klasteru sa pripadnošću određenoj dijagnostičkoj kategoriji. Iz sledeće tabele (Tabela 3) se vidi da pripadnost klasterima ne razvrstava jasno ispitanike sa različitim dijagnostičkim kategorijama, naročito u slučaju prva tri klastera gde se nalaze ispitanici svih dijagnostičkih kategorija. Ipak, Pirsonov hi-kvadrat koeficijent potvrđuje da postoji statistički značajna povezanost između pripadnosti klasteru i dijagnostičkoj kategoriji. (Tabela 4)

Tabela 3. Kontingencijska tabela

\begin{tabular}{|c|c|c|c|c|c|c|c|}
\hline & & & klasteri & & & & \\
\hline Dijagnoza & $\begin{array}{l}\text { Obeshrab- } \\
\text { ren } \\
\text { Internal. }\end{array}$ & $\begin{array}{c}\text { Ume- } \\
\text { reni }\end{array}$ & $\begin{array}{l}\text { Samou- } \\
\text { ver. In- } \\
\text { ternal. }\end{array}$ & $\begin{array}{l}\text { Bespomo } \\
\text { ćni } \\
\text { eksternal } \\
.\end{array}$ & $\begin{array}{l}\text { Samou- } \\
\text { ver. Ek- } \\
\text { sternal. }\end{array}$ & $\begin{array}{c}\text { Situaci } \\
\text { oni } \\
\text { optimis } \\
\text { ti }\end{array}$ & Total \\
\hline $\begin{array}{l}\text { Anks- } \\
\text { depres. }\end{array}$ & 7 & 14 & 7 & 4 & 7 & 4 & 43 \\
\hline $\begin{array}{l}\text { Somato- } \\
\text { form. }\end{array}$ & 2 & 10 & 2 & 8 & 3 & 0 & 25 \\
\hline $\begin{array}{l}\text { Depresiv- } \\
\text { ni }\end{array}$ & 16 & 7 & 4 & 6 & 2 & 3 & 38 \\
\hline $\begin{array}{l}\text { Por. lično- } \\
\text { sti }\end{array}$ & 3 & 3 & 3 & 2 & 3 & 0 & 14 \\
\hline Panični & 1 & 3 & 5 & 0 & 0 & 0 & 9 \\
\hline Total & 29 & 37 & 21 & 20 & 15 & 7 & 129 \\
\hline
\end{tabular}


Tabela 4. Hi-kvadrat Test

\begin{tabular}{lccc}
\hline & & & Nivo \\
& Vrednost & Stepeni slobode & $\begin{array}{c}\text { značajnosti } \\
\text { Pirsonov Hi-kvadrat }\end{array}$ \\
\hline
\end{tabular}

Da bi ispitali odnos između klastera i indeksa uznemirenosti, urađena je analiza varijanse. Analiza je ukazala na postojanje statistički značajnih razlika u pogledu nivoa indeksa uznemirenosti među klasterima. (Tabela 5)

Tabela 5. Anova: testiranje značajnosti razlika između klastera

\begin{tabular}{lrc}
\hline St. slobode & $\mathrm{F}$ & $\mathrm{p}$ \\
\hline 5 & 8.85 & .00 \\
\hline
\end{tabular}

Post hoc analizom (Scheffe test, Tabela 6) je utvrđeno među kojim klasterima postoje statistički značajne razlike u pogledu nivoa indeksa uznemirenosti. To su klasteri obeshrabreni internalisti (klaster br.1) i samouvereni internalisti (br.3), kao i klasteri samouvereni internalisti (br.3) i bespomoćni eksternalisti (br.4).

Tabela 6. Post hoc testiranje statističke značajnosti razlika među klasterima, indeks uznemirenosti Scheffe test

\begin{tabular}{llccccc}
\hline Broj klastera & $\{1\}$ & $\{2\}$ & $\{3\}$ & $\{4\}$ & $\{5\}$ & $\{6\}$ \\
\hline AS & 2.14 & 1.68 & 1.00 & 2.27 & 1.45 & 1.36 \\
\hline 1 & & & & & & \\
2 & .28 & & & & & \\
3 & .00 & .05 & & & & \\
4 & .99 & .15 & .00 & & & \\
5 & .13 & .96 & .67 & .07 & & \\
6 & .28 & .95 & .94 & .17 & .99 & \\
\hline
\end{tabular}

Ovi rezultati postaju jasni kada se pogledaju aritmetičke sredine klastera u pogledu indeksa uznemirenosti (Tabela 7). One ukazuju da je nivo indeksa uznemirenosti u proseku najviši u klasteru bespomoćni eksternalisti, a najniži u klasteru samouvereni internalisti, što objašnjava njihovo međusobno razlikovanje.

Analizom ovih rezultata se uočava sledeća pravilnost, što je u jednom klasteru viši nivo specifične self-efikasnosti, to je niži nivo indeksa uznemirenosti. Analogni odnos prethodno navedenom je i odnos gde se sa porastom nivoa percepcije kontrole, smanjuje nivo indeksa uznemirenosti (Tabela 7). 
Tabela 7. Prikaz prosečnih vrednosti na merama specifične self-efikasnosti, percepcije kontrole $i$ indeksa uznemirenosti

\begin{tabular}{lcccccc}
\hline klasteri & $\begin{array}{l}\text { Obeshrab. } \\
\text { internalisti }\end{array}$ & Umereni & $\begin{array}{l}\text { Samouver. } \\
\text { inernalisti }\end{array}$ & $\begin{array}{l}\text { Bespomoćni } \\
\text { eksternalisti }\end{array}$ & $\begin{array}{l}\text { Samouver. } \\
\text { eksternalisti }\end{array}$ & $\begin{array}{l}\text { Situacioni } \\
\text { optimisti }\end{array}$ \\
\hline SSSE & 42.62 & 51.44 & 60.77 & 37.47 & 58.40 & 58.46 \\
PK & 43.14 & 48.44 & 60.87 & 40.30 & 57.86 & 64.92 \\
IU & 2.14 & 1.68 & 1.00 & 2.27 & 1.45 & 1.36 \\
\hline
\end{tabular}

Napomena. IU = indeks uznemirenosti

Ovakvi rezultati upućuju na zaključak o ključnom delovanju varijabli percepcije kontrole i specifične self-efikasnosti u smislu da postoji pozitivna povezanost između poverenja pacijenta u svoje sposobnosti da uspešno završi svoj tretman i doživljaja da su mu na raspolaganju svi faktori koje on smatra važnima da bi se terapija dobro završila. S druge strane, utisak je na osnovu dobijenih rezultata da su varijable lokusa kontrole i generalizovane self efikasnosti od sekundarnog značaja. S obzirom da na osnovu do sada urađenih analiza nemamo precizan odgovor na ovo pitanje prediktivne moći pojedinačnih mera očekivanja na stanje uznemirenosti pacijenata, uradili smo i regresionu analizu sa merama očekivanja ishoda tretmana kao prediktorskim varijablama i indeksom uznemirenosti kao kriterijskom varijablom. Rezultati su sumirani u tabeli br. 8 .

Tabela 8. Regresija varijable indeks uznemirenosti na mere očekivanja ishoda tretmana

\begin{tabular}{|c|c|c|c|c|}
\hline $\mathrm{R}$ & $\mathrm{R}^{2}$ & $\begin{array}{c}\text { Standardna greška mere- } \\
\text { nja }\end{array}$ & $\mathrm{F}$ & Značajnost $\mathrm{F}$ \\
\hline .56 & .32 & 64.20 & 19.23 & .00 \\
\hline \multicolumn{2}{|c|}{ Prediktori } & Beta & $\mathrm{t}$ & Značajnost t \\
\hline \multicolumn{2}{|c|}{$\begin{array}{l}\text { Percepcija kontro- } \\
\text { le }\end{array}$} & -.30 & -3.19 & .00 \\
\hline \multicolumn{2}{|c|}{$\begin{array}{l}\text { Gener. self- } \\
\text { efikasnost }\end{array}$} & -.25 & -2.80 & .01 \\
\hline \multicolumn{2}{|c|}{ Lokus kontrole } & -.21 & -2.64 & .01 \\
\hline
\end{tabular}

Ova analiza je pokazala pomalo iznenađujuće rezultate pošto je specifična self-efikasnost ispala sa liste prediktora jer njena parcijalna korelacija sa kriterijumom nije dostigla nivo značajnosti. Iako je korelacija ove mere sa kriterijumom značajna $(r=-0,41, p=0,00)$, kada se uradi parcijalna korelacija sa 
kontrolom varijable percepcije kontrole, ova korelacija se gubi ( $\mathrm{r}=-0,11, \mathrm{p}=$ 0,21). Mera percepcije kontrole i mera specifične self-efikasnosti su i inače u međusobno najvišoj korelaciji $(\mathrm{r}=0,69, \mathrm{p}=0,00)$. To ukazuje na to da specifična self-efikasnot ostvaruje svoju vezu sa stepenom uznemirenosti preko percepcije kontrole. (Tabela 9.)

Tabela 9. Koeficijenti korelacije

\begin{tabular}{llllll}
\hline & 1 & 2 & 3 & 4 & 5 \\
\hline 1. Spec. self-efikasnost & - & & & & \\
2. Spec. lokus kontrole & $.31^{* *}$ & - & & & \\
3. Percepcija kontrole & $.69^{* *}$ & $.35^{* *}$ & - & & \\
4. Gen. self-efikasnost & $.44^{* *}$ & .03 & $53^{* *}$ & - & \\
5. Indeks uznemirenosti & $-.41^{* *}$ & $-.30^{* *}$ & $-.49^{* *}$ & $-.41^{* *}$ & - \\
\hline
\end{tabular}

Napomena: ${ }^{* *} \mathrm{p}<.01$

\section{Diskusija}

U ovom istraživanju predmet merenja su bila očekivanja kod pacijenata koji se nalaze na psihijatrijskom lečenju. Pri tome, ova očekivanja su se odnosila na procenu uspeha samog psihijatrijskog tretmana. Osnovno istraživačko pitanje je bilo kako se ova očekivanja vezana za ishod tretmana odnose međusobno, a kako prema vrsti i intenzitetu patologije kod ispitanika.

Rezultati ukazuju da se po merenim očekivanjima formiraju različiti profili $t j$. da se može razlikovati barem šest grupa pacijenata koji unutar grupe imaju slične, a među grupama različite strukture očekivanja. Najviše se razlikuju oni ispitanici koji poseduju visoka očekivanja self-efikasnosti i kontrole, a unutrašnji lokus kontrole (samouvereni internalisti), od onih koji poseduju niska očekivanja self-efikasnosti i kontrole, uz spoljašnji lokus kontrole (bespomoćni eksternalisti). Ove grupe se statistički značajno razlikuju i po dijagnostičkim kategorijama i po indeksu uznemirenosti.

Veza između dijagnostičkih kategorija nije, međutim, potpuno jasna. Uočljivo je postojanje nekoliko profila očekivanja unutar jedne dijagnostičke kategorije. Ispitanici sa istim dijagnozama nemaju homogene profile po pitanju mera očekivanja. Ovaj rezultat indirektno potvrđuje dobro poznatu činjenicu da su 
pojedine dijagnostičke kategorije veoma široke i po raznovrsnosti simptoma, i po mogućem intenzitetu smetnji. To je naročito vidljivo kod poremećaja iz reda anksiozno depresivnih i depresivnih poremećaja. Ranija istraživanja ukazuju na povezanost depresije i unutrašnjeg lokusa kontrole vezanog za negativan ishod (Novović, Kosanović, Biro i Smederevac, 2001). Slično važi i za teorijsku pretpostavku o povezanosti niske self-efikasnosti i percepcije kontrole sa depresivnim i anksioznim poremećajima (Bandura 1994). Pravilnost koja bi datu pretpostavku potvrdila, nije pronađena u našem istraživanju. Naime, ispitanici koji pripadaju dijagnostičkim kategorijama depresije i anksiozne depresije i pored postojanja trenda, ipak nisu ujednačeni ni po orijentaciji ka unutrašnjem lokusu kontrole, ni po nivou self-efikasnosti, ni po nivou percepcije kontrole. Nalaze se skoro u svim dobijenim klasterima i očekivanja im se kreću od izuzetno visokih, do veoma niskih vrednosti. Očigledno je da u okviru dijagnostičke kategorije kao što je depresija postoje podkategorije u odnosu na strukturu očekivanja ishoda tretmana. Kod kategorije paničnog poremećaja, koji ima ograničen spektar jasnijih simptoma, lakše je uočiti pravilnosti u odnosu na karakteristike očekivanja ishoda tretmana.

Ono što su za nas bila naročito provokativna pitanja na koja smo pokušali da odgovorimo ovim istraživanjem je kakav je uticaj interakcije različitih mera očekivanja ishoda tretmana na izraženost indeksa uznemirenosti. Već na prvi pogled je postalo jasno da rezultati analize odnosa između profila očekivanja ishoda $\mathrm{i}$ indeksa uznemirenosti govore u prilog teorijskim pretpostavkama da su pozitivna očekivanja ishoda povezana sa boljim stanjem pacijenata. Zanimala nas je i detaljnija analiza specifičnog uticaja pojedinačnih mera i njihove interakcije. Tu dolazimo do rezultata koji govore o tome da se percepcija kontrole izdvaja kao najdosledniji i najznačajniji prediktor dobrog stanja pacijenta, zatim da postoji značajna povezanost i značajno preklapanje u uticaju između specifične self efikasnosti i percepcije kontrole, kao i da je, iako je lokus kontrole nisko, ali značajno povezan sa stanjem pacijenta, njegov uticaj ipak zavistan od uticaja percepcije kontrole. Slične rezultate ističu još neki istraživači. Tako Ajzen (2002) navodi rezultate meta analitičke studije koja je pokazala da ajtemi mera percepcije bihejvioralne kontrole formiraju dva faktora self-efikasnost i kontrolabilnost. Teorija planiranog ponašanja opisuje ovu vezu kao vezu između dva srodna pojma sa zajedničkim, hijerarhijski nadređenim pojmom, percepcijom bihejvioralne kontrole. Posmatrajući selfefikasnost i percepciju kontrole kao srodne manifestacije šireg pojma, među njima je opravdano očekivati visoku povezanost što smo i mi u našem istraživanju potvrdili. 
Što se tiče odnosa između lokusa kontrole i percepcije kontrole u dostupnoj literaturi, očigledno je da postoji tendencija da se unutrašnji lokus kontrole pomeša sa posedovanjem kontrole, a spoljašnji lokus kontrole sa doživljajem da se nema kontrola nad događajima. Međutim, dalja analiza pokazuje da procena kontrole nad ishodima može biti nezavisna od internalnosti, odnosno eksternalnosti (Ajzen, 2002). Kada ljudi veruju da poseduju potrebna sredstva ili prilike (veštine, sreću, pomoć drugih ljudi itd.) i da eventualne prepreke na tom putu mogu savladati, oni će pokazati visok nivo kontrolabilnosti. Percepcija da su ta sredstva ili prepreke unutrašnje ili spoljašnje prirode, neće ovo promeniti. Naši rezultati potvrđuju ovo stanovište. Naime, vidimo da je očekivanje posedovanja kontrole povezano sa boljim stanjem pacijenata, nezavisno od njihove sklonosti da uzroke neuspeha traže u unutrašnjim (samouvereni internalisti) ili spoljašnjim faktorima (samouvereni eksternalisti) i obrnuto.

U ranijim istraživanjima je zaključeno je da je u proceni negativnih situacija korisniji spoljašnji lokus kontrole. (Abramson et al, 1978). Međutim, postavlja se pitanje da li je, kada osoba treba da menja nešto od svog ponašanja ili razmišljanja (kao što je to slučaj u učešću u psihijatrijskom lečenju) poželjno da stvarnost opaža kao nezavisnu od svojih akcija. Motivacija za promenu kod osoba sa ovakvom orijentacijom može biti problematična. Dakle, pitanje poželjnosti zavisi od toga da li kod osobe, u ovom slučaju psihijatrijskog pacijenta, želimo da razvijemo osećaj odgovornosti i kontrole nad svojim životom ili da umanjimo osećaj krivice, samooptuživanja, a povećamo motivisanost za promenu. Rezultati našeg istraživanja osvetljavaju ovo pitanje iz nešto šireg ugla, uzimajući u obzir i odnos sa self-efikasnošću i percepcijom kontrole. Kao što smo rekli - naši rezultati više inkliniraju zaključku da nije od velike važnosti koja će orijentacija specifičnog lokusa kontrole biti kod onih ispitanika koji imaju visok nivo self-efikasnosti i percepcije kontrole u situaciji psihijatrijskog tretmana. Oni poseduju pozitivniju samoocenu, veruju u svoje snage i imaju manje izražene simptome, te je gotovo svejedno da li procenjuju da li su za eventualne negativne ishode odgovorni sami ili je za to zaslužna neka spoljna varijabla. Tako da se može zaključiti da poželjnost orijentacije specifičnog lokusa kontrole zavisi, kako od samog kriterijuma na osnovu koga poželjnost procenjujemo, tako i od sadejstva sa ostalim očekivanjima ishoda tretmana.

Analogno sa prethodnim, postoji mišljenje da su očekivanja self-efikasnosti odraz isključivo unutrašnjih faktora. Međutim, neki autori smatraju da je procena sopstvene efikasnosti konceptualno nezavisna od mesta lokusa. Naime, osoba može da veruje da će biti uspešna u terapiji jer je sigurna u sopstvene 
sposobnosti ili zato što misli da je boravak na klinici dovoljan za uspeh u lečenju. (Ajzen, 2002). I naši rezultati upućuju na to da se self-efikasnost i lokus kontrole trebaju posmatrati posebno, pošto ostvaruju očekivan povezan ali i u izvesnoj meri drugačiji uticaj kada je u pitanju izraženost simptomatologije.

Iz svega do sada rečenog, dolazimo do toga da rezultati našeg istraživanja ukazuju na potrebu da se, tokom psihijatrijskog lečenja, vodi računa o očekivanjima pacijenata o ishodu tretmana. Na osnovu poznavanja ovih očekivanja i njihovog međusobnog odnosa kod pacijenata, kliničarima će potencijalno biti olakšan odabir i raspored intervencija, kao i date smernice u kom pravcu motivisati klijente na promenu.

Na kraju ćemo se dotaći smernica za buduća istraživanja. Na prvom mestu, poželjno bi bilo poboljšati karakteristike Skale specifičnog lokusa kontrole. Predlaže se da na svaki ajtem ispitanici odgovaraju stepenom slaganja izraženog kroz skalu Likertovog tipa. Zatim bi bilo korisno organizovati longitudinalnu studiju u kojoj bi se pratile promene u očekivanjima klijenata tokom trajanja terapije kao i uticaj ovih očekivanja na sam tok terapije i njen ishod.

\section{Zaključak}

Rezultati analize međusobnog odnosa očekivanja ishoda tretmana govore o postojanju šest grupa ispitanika čije se razlike smisleno mogu interpretirati. Najviše se razlikuju oni ispitanici koji poseduju visoka očekivanja selfefikasnosti, percepcije kontrole i unutrašnji specifični lokus kontrole, od onih koji poseduju niska očekivanja self-efikasnosti, percepcije kontrole i spoljašnji specifični lokus kontrole.

Ove grupe se statistički značajno razlikuju i po dijagnostičkim kategorijama i po indeksu uznemirenosti. Veza između dijagnostičih kategorija i klastera nije potpuno jasna. Uočljivo je postojanje nekoliko profila očekivanja unutar jedne dijagnostičke kategorije, kao i to da ispitanici sa istim dijagnozama nemaju homogene profile po pitanju mera očekivanja ishoda tretmana.

Ispitujući odnos između profila očekivanja ishoda tretmana i indeksa uznemirenosti, dolazimo do toga da se percepcija kontrole izdvaja kao najdosledniji i najznačajniji prediktor dobrog stanja pacijenta. Rezultati takođe ukazuju na značajnu povezanost i značajno preklapanje u uticaju između specifične self efikasnosti i percepcije kontrole, kao i da je, iako je specifični lokus kontrole nisko ali značajno povezan sa stanjem pacijenta, njegov uticaj ipak zavistan od uticaja percepcije kontrole. 


\section{Reference}

Abramson, L.Y, Seligman M.E.P. and Teasdale, J.D. (1978). Learned helplessness in humans: Critique and reformulation. Journal of Abnormal Psychology, 87, 49-74.

Ajzen, I. (2002). Perceived behavioral control, self-efficacy, locus of control and the theory of planned behavior. Journal of Applied Social Psychology, $32,1-20$.

Amroš, J. (2006). Merenje psihopatoloških simptoma i opštih indikatora uznemirenosti pomoću samoopisnog upitnika: Ček lista simptoma-90-R. Diplomski rad, Novi Sad: Filozofski fakultet

Bandura, A. (1982). Self-efficacy mechanism in human agency. American Psychologist, 37, 122-14.

Bandura, A (1994). Self-efficacy, Encyclopedia of human behavior, Academic Press, 4, 71-81. Posećena 01.07.2007, na internet stranici: http://www.des.emory.edu/mfp/BanEncy.html

Beitel, M., Ferrer, E. \& Cecero, J. J. (2004). Psychological mindedness and cognitive style Journal of Clinical Psychology, 60, 567-582.

Brewin, C.R, (1988). Cognitive foundations of clinical psychology, LEA publishers Ltd, U.K.

Brewin, C.R.\& Shapiro, D. A.(1984). Beyond locus of control .Attributions of responsibility for positive and negative outcomes, British Journal of Psychology, 75, 43-49.

Burger, J.M. \& Cooper, H.M.(1979). The desirability of control, Motivation and Emotion, 3, 381-393.

Derogatis, L.R. and Savitz, K.L. (1999) The use of psychological testing for treatment planning and outcomes assessment, M. E. Maruish (Ed.) The CSL-90-R, Brief Symptom Inventory and Matching Clinical Rating Scales, 679-724.

Forsterling, F. (1988). Attribution theory in clinical psychology. U.K: John Wiley \& Sons.

Furnham A \& Steele H.(1993). Measuring locus of control: a critique of general, children's, health and work-related locus of control questionnaires, British Journal of Psychology, 84, 443-479.

Gavrilov-Jerković, V. (2003). Relacija spremnosti za promenu i efekta tretma- 
na u kontekstu transteorijskog modela promene, Doktorska disertacija, Novi Sad: Filozofski fakultet.

Gavrilov-Jerković, V. (2007). Relation between stages of change and motivation in the treatment of psychiatric patients, Psihologija, 40, 245-262.

Jerković, I. i Gavrilov-Jerković, V. (1997). Nivoi kauzalnih atribucija. Psihologija, 4, 379-394.

Jerković, I. (2003). Kauzalne atribucije roditelja kao formativni uticaj u razvoju enureze kod dece. Psihologija, 1, 73-87.

Musher-Eizenman, D. R., Nesselroade, J. R. \& Schmitz, B. (2002). Perceived control and academic performance, International Journal of Behavioral Development, 26, 540-547

Nir, Z. \& Neumann, L. (1995). Relationship among self-esteem, internalexternal locus of control, and weight change after paticipation in a weight reduction program. Journal of Clinical Psychology, 51, 482-490.

Novović, Z., Kosanović, B., Biro, M. i Smederevac, S. (2001). Veza između atribucionog stila, anksioznosti i depresije. Psihologija, 1-2, 139-154.

Olsen, L.R. et al. (2004). The SCL-90 and SCL-90R versions validated by item response models in Danish community sample. Acta Psychiatrica Scandinavica, 110, 225-229.

Rotter, J.R. (1954). Social learning and clinical psychology. New York: Prentice-Hall, Inc.

Suyder, C.R. \& Forsyht, D.R.(1990). Handbook of social and clinical psychology, The Health Perspective, Pergamon Press, New York

Schwarzer, R. \& Jerusalem, M (1999). Scales for measurement of teachers and students characteristics. Berlin: Freie Universitat

Schwarzer, R. \& Jerusalem, M (2002). Psychometry scales overview, Posećena 12.08.2007, na internet stranici: http://www.fu-berlin.de/gesund/e.htm

Weiner, B. (1992). Human motivation: Metaphor, theories and research. Newbury Park, London, New Delhi: SAGE Publication, Inc. 


\title{
ABSTRACT
}

\section{CORRELATION BETWEEN TREATMENT EXPECTANCY AND CLINICAL PIC- TURE IN PSYCHIATRIC PATIENTS}

\author{
Dragana Brdarić and Vesna Gavrilov-Jerković
}

We were interested in exploring the relation between expectancy for change in psychiatric patients and treatment outcome, as well as in exploring the relation between expectancy for change and the type and expression of the problems that had led to their current psychiatric treatment.

Four types of the treatment expectancies were examined: specific locus of control, specific and general self-efficacy, and perceptions of control. The following clinical variables were examined: diagnosis and distress index (Global index of illness severity). The research was carried out on 129 respondents who received treatment in psychiatric institutions in Vojvodina.

A cluster analysis confirmed an existence of six interpretable groups of respondents concerning their treatment expectancies: discouraged patients with an internal locus of control, patients with average scores, self-confident patients with an internal locus of control, helpless patients with an external locus of control, self-confident patients with an external locus of control, and situational optimists.

Further analyses indicated that there were statistically significant differences among the clusters concerning their distress index and diagnosis. The results support the hypothesis that high expectations of control and efficacy are related to better psychiatric condition of the respondents. However, there was a complex pattern of relations among individual measures of treatment expectancy. Perceptions of control appeared to be the best predictor of treatment outcome. Although it was suggested that a change toward an internal locus of control was associated with a better psychiatric status, the effects of specific locus of control seem unclear, inconsistent and dependent on the other treatment expectancy measures.

Key words: expectancy, locus of control, self-efficacy, perceptions of control, psychiatric patients 